\title{
THE ROLE OF TEACHING ISLAMIC RELIGION AT SEKOLAH ALAM INDONESIA PALEMBANG
}

\author{
Aida Imtihana; Sukirman; Mardeli; Nurlaila \\ Raden Fatah State Islamic University of Palembang, Indonesia \\ Email: aida.imtihana@gmail.com
}

\begin{abstract}
The weakness of the schools in the emergence of Islamic education curriculum is the lack of facilities provided for the benefits of its curriculum. Islamic education curriculum in schools is systematic, so it cannot resolve the issue of the overall gap because it is limited to the other aspects like a limited time allocation. Therefore, Sekolah Alam Indonesia Palembang was established to optimize the learning of Islamic education. The results of this study showed that the learning process of Islamic education at the school has been in accordance with the theory of planning, implementation, and evaluation. The planning instruction consists of an annual, semester, weekly and daily program planning. In practice, the learning process is based on the planning that has been made. Further, to evaluate the learning process, oral and written tests were conducted.
\end{abstract}

Keywords: Islamic Education, Sekolah Alam

\section{A. Introduction}

The Islamic education is education that provides knowledge and forms the attitude, personality, and skills of the students in the practice of their religion, which is carried out at least through the subjects / courses on all lines, levels and types of education. It creates Indonesian citizens who faith and fear of God, have good behavior and are able to maintain the peace and harmony among religions (Government Regulation No. 55 Year 2007 Article 2 Paragraph 1 P). 
In carrying out the mandate of Islamic education, problems commonly arise both internal and external related to how should Islamic education was carried out or implemented. Many influences that led to the implementation of Islamic education has problems and challenges, includding the impact of globalization, economic, social, cultural, technological and many other influences.

Based on the problem, nowadays there are many alternative schools are offered by several educational institutions in order to optimize the Islamic education such as Boarding School, Home Schooling, Nature School and the other alternative educations. The alternative schools or educational institutions would have the advantages and also the weaknesses.

Nature School does not force the students to master a particular subject. The method used is in the form of active learning. It means that the activities in the teaching and learning process are not only teacher-centered, but also student centered. In addition, children will also be aware of the environment. Nature School really liberates the students to develop the personal talents they have. So, since they are young they have been taught to appreciate the differences. They become the good character people and also have wide horizons of science.

At the Nature School, there is no classrooms such as in general school, there is only hut as a place to learn. It is not only learning with relaxing atmosphere and without pressure but also full of motivation. It makes the children encouraged to demonstrate their skills in various ways.

From the various advantages of the Nature School described above, the potential of the students will be distributed or facilitated, so that it will be developed optimally. It means that not only promoting cognitive aspects, but there are aspects of affective and psychomotor aspects as well. In addition, education at the Nature School can be used as a reference for Islamic education in other alternative schools.

Based on the background above, the writers are interested in doing a research at Sekolah Alam Indonesia Palembang and 
investigate how the school conducts the planning, implementation and evaluation, especially in Islamic education subject.

\section{B. Theoretical Framework}

\section{Teaching}

According to the Constitution No. 20 about the system of national education article 1 paragraph 20, Learning is a process of interaction of the students with the teachers and learning resources in a learning environment. Hamalik (1994: 40) said that learning is a structured combination that includes the elements of human, material, facilities, equipments and procedures that most affect the learning objectives achievement. Simply, learning can be defined as a product of continuous interaction between the development and the life experience. More complex, learning means a conscious effort from a teacher to teach the students (directing the interaction of the students with the other learning resources) in order to achieve the expected goals.

\section{The Definition of Islamic Education}

Education is a conscious and deliberate effort to create a learning atmosphere and active learning process to develop the students' potential to have the spiritual power of religion, self-control, personality, intelligence, moral and skills which are need by themselves, their society, nation, and country, in accordance with the republic of Indonesia Constitution No. 2 Year 2003 concerning the national education system Article 1 (1945, 2004: 3).

Daradjat (1996: 86) states that Islamic education or at-Tarbiyah Islamiyah is an effort to guide and care for the students so that after they finish their education later, they can understand and practice the teachings of Islam. Islamic education is an activity that aims to produce religious people, thus the Islamic education needs to be driven toward the growth of moral and character (Zuhairini, 2004: 1).

So, Islam includes the teachings about living system which covers all aspects of human life. The teaching of Islam contains basic 
guidelines that should be used to set up a prosperous life now and hereafter. Thus, the scope of the teaching of Islam is very immense, covering all aspects of human life.

\section{The Fundamentals of Islamic Education}

a. Al-Qur'an

Al-Qur'an is the of God revealed to the prophet, Muhammad, and reading it is a worship (al-Qattan, nd: 17). Al-Qur'an is the holy guidance for Muslims to behave, both in relation to Allah (vertical) and with fellows (horizontal). As a rule of life, Al-Quran has a broad scope and persuasive approach in guiding human as a form of educational process.

b. As-Sunnah/Hadits

As-Sunnah are all the words, deeds, and provisions of Muhammad. As al-Qur'an, Sunnah is also the second principal source of Islamic education that contains many principles of education for Muslims. The Prophet Muhammad is a great educator in the Islamic world, he is in second place after Allah for Muslims.

Thus, the presence of Muhammad as a prophet actually cannot be separated from his existence as an educator.

c. Ijtihad

Ijtihad is the deployment of the ability of a faqih (Islamic jurist) to produce a strong presumption about the syar'i law (Syarifuddin, nd: 225). Or in the other words, ijtihad is the effort to devote all the ability to formulate Islamic rules in a way of istinbatt from Al-Qur'an and Sunnah, using rational ability to formulate laws that are not explicitly mentioned in the Qur'an and Sunnah.

\section{The Objective and Function of Islamic Education}

According Marimba (nd: 73), the purpose of Islamic education is the establishment of a Muslim's personality, it means that the entire Muslim personality aspects, such as good behavior, good philosophy 
of life and beliefs. While, the function of Islamic education is as a tool to increase the faith and devotion to Allah.

\section{The Planning of Islamic Education Learning}

Learning activities that take place in the formal school, intentionally, planned with the guidance of teacher and the other educators support. Learning activities are carried out intentionally and prepared in the form of teaching planning, it is as an integral activities of the learning process in schools. The preparation of learning programs can be divided into the annual program, the semester program, weekly program, and the daily program.

\section{a. Learning Implementation}

Learning implementation is a core activity of the whole learning process. The learning implementation should include three things: a) Opening; b) Delivering; and c) Closing (Susanto, 2013: 49).

b. Evaluation

Sudjana as citied in Soetopo (2011: 165) explains that evaluation basically gives the consideration or price or value based on specific criteria. Evaluation phase conducted is to assess students' understanding of the material that has been delivered.

So, it can be concluded that the evaluation is a tool to measure the success or failure, or the achievement of the desired learning.

c. Nature School

According to Thohir, the Nature School is one of the alternative educations that use nature as the main media in teaching the students. Nature School appears as a form of developmental awareness so as to achieve what is referred as 'critical awareness' as one of the characteristics which are marked by creating a new system that is different from the old one.

The school curriculum still refers to the Ministry of National Education, but the Nature School has its own concepts in developing the concept of nature based-school. 
The method used in the Nature School teaching is called as Spider Web System, it is a theme that is integrated into all subjects. So that the knowledge gained is not just memorization, but the result of the students' experiences and discoveries (http://mifzawal.blogspot.com/2008/11/konsep-sekolahalam.html).

Thus, the Nature School is an alternative education that gives variety in the world of education. Nature School tries to popularize the methods used by the Prophet which makes the leader in earth, or khalifah fil ard a leader who has good character and strong mentality.

\section{Methodology}

The design of this study is descriptive. According Antherton and Klemmack in Soehartono (1995: 33), descriptive study conducted in order to obtained a clear description of the research subject as well as the phenomenon to be observed. Descriptive research as the design of this study is also related to the collected data. In the descriptive study, the data collected is in the form of words, pictures, and not numbers. Thus, the research report contains the quotations of data to illustrate the presentation of the report. Such data may be derived from the text, interviews, field notes, photographs, videos, tapes, personal documentation, notes or memos, and other official documents.

The subjects of the study are the objects, thing or person and the place where the data in question is attached. Then to differentiate the respondents and the data sources, it is explained that the respondents are people who can respond by providing the information about the research data. Those who became the subjects of this study are the principal, staff, teachers, and students.

In this study, the writers collect the primary and secondary data. Primary data in this study is interview which is a form of communication between two people, involving someone who wants to obtain information from the other by asking questions, based on a specific goal. Observation is a directly done by the writers, without 
asking questions to the object of study. While, secondary data is data to support and strengthen the primary data.

According to Bogdan and Biklen, data analysis is the process of finding and arranging systematically the transcript of the interview, the record in the field, and the other data has been obtained, all of which was collected to enhance the understanding of the writers (on a phenomenon) and help them to present their findings to others.

In the qualitative research, the data analysis carried out simultaneously or nearly along with the data collection. The following figure is the procedures of analyzing the data in a qualitative study according to Irawan which is used in this study.

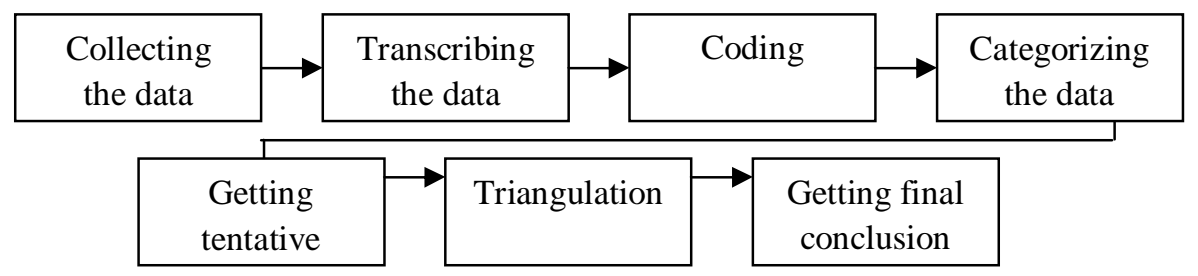

\section{Result of the Study}

1. Lesson Planning at Sekolah Alam Indonesia Palembang

At Sekolah Alam Indonesia, all teachers are required to arrange all of the annual and semester planning, weekly and daily activities units and submit all of them to the principal. All components of the learning device are signed by the principal and the teachers themselves. The principal obliges all teachers to submit the learning components and complete the requirements before the new school year begins in early August. At Sekolah Alam Indonesia, teaching and learning activities planning is divided into the annual, semester, weekly activities and daily activities planning. For more details about the activities program at Sekolah Alam Indonesia, it is explained as follows:

a. Annual program planning

Annual program planning is a learning program in which the capabilities and habituation-conditioning skills expected to be achieved by the students in one year have been established and structured. The annual program activities are 
carried out by Sekolah Alam Indonesia consists of varied activities that include: First, visiting out. It is learning activities conducted by visiting places of learning resources directly to obtain the information or knowledge that support the learning materials. Second, celebrating the feast day. It is carried out with many activities such as competitions, art performing, parade, and religious discourse (lectures) and many others. Third, cheerful charity program. It is a social activity that aims to foster the students' social awareness in helping the people in need, like what they have done was to help the disaster victims in Palestine. Besides that, this charity program is also intended for helping the community in need around the school, such as grocery donations for the poor and infaq for the orphanage. Fourth, the medical examination. This activity aims to raise the healthy living awareness and familiarize the students on paramedical professions which consist of the measurement of height and weight, nutrition, dental and psychology examination. Fifth parent participation. It is an activity involving the parents to participate in learning activities, as a guest speaker, assistant teacher and others. Sixth, the exhibition works. It is done to foster students' confidence by presenting their work in the class, so it can foster their positive self-concept and motivate them to develop their creativity. Seventh, the art performing. It is done to foster the Students' courage and confidence to present in public and show their abilities.

b. Semester Program Planning

Semester program planning is a learning program that contains the outlines of things to be done and achieved in the semester, it is a translation of the annual program. Syllabus is a set of plans and setting learning activities, classroom management, and assessment of learning outcomes. 
c. Weekly Program Unit

The table of weekly program at Sekolah Alam Indonesia includes the activity of memorizing Alqur'an with 5 surah achievement target.

\section{Table 1}

Sheet of Weekly Report

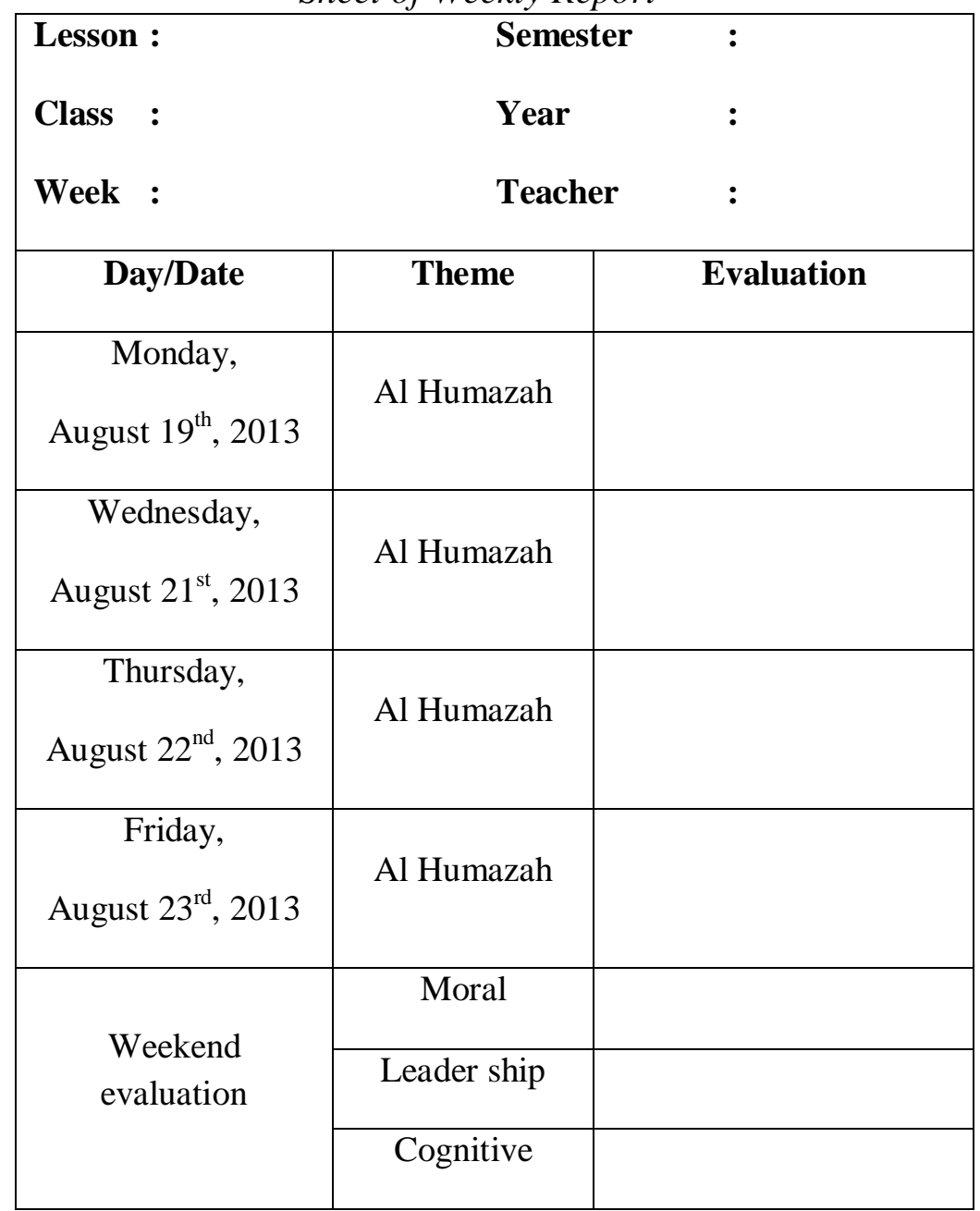

d. Daily Program Unit

Planning daily activities are the elaboration of a weekly program. The implementation can be in group, individual, or 
classical in one day. In the daily planning, teachers should develop daily activities units. Daily Activities Unit in the Sekolah Alam Indonesia in the form of delivering Islamic education theory presented by each class teacher, followed by the core activities or regular learning. The learning time allocation at Sekolah Alam Indonesia:

Table 2

Learning Time Allocation

\begin{tabular}{|c|c|c|}
\hline Class & Day & Time Allocation \\
\hline $1^{\text {st }}$ grade & Monday - Friday & $07.30-13.00$ \\
\hline $2^{\text {nd }}$ grade & Monday - Friday & $07.30-14.30$ \\
\hline $3^{\text {rd }}-6^{\text {th }}$ grade & Monday - Friday & $07.30-15.30$ \\
\hline
\end{tabular}

Students at the school regularly memorize the surah in Al-Qur'an and are targeted to memorize all of 30 juz until the end of their $5^{\text {th }}$ grade. More detail example of the daily program units are the activities of tahsin guidance, learning to read Al-Qur'an. The method used in the tahsin guidance is tahsin Utsmani. The indicator is the students are able to recite the ayat of the Al-Quran with the correct and clear mahraj, the students would recite it without being forced, the students are able to read the ayat of Al-Quran according its volumes. Tool or its source is the book Tahsin al-Quran Guidance and Tajweed. For assessing the students' development, they should be able to read Al-Quran in accordance of its volumes in a loud voice. 
Table 3

Lesson Plan of Al-Qur'an

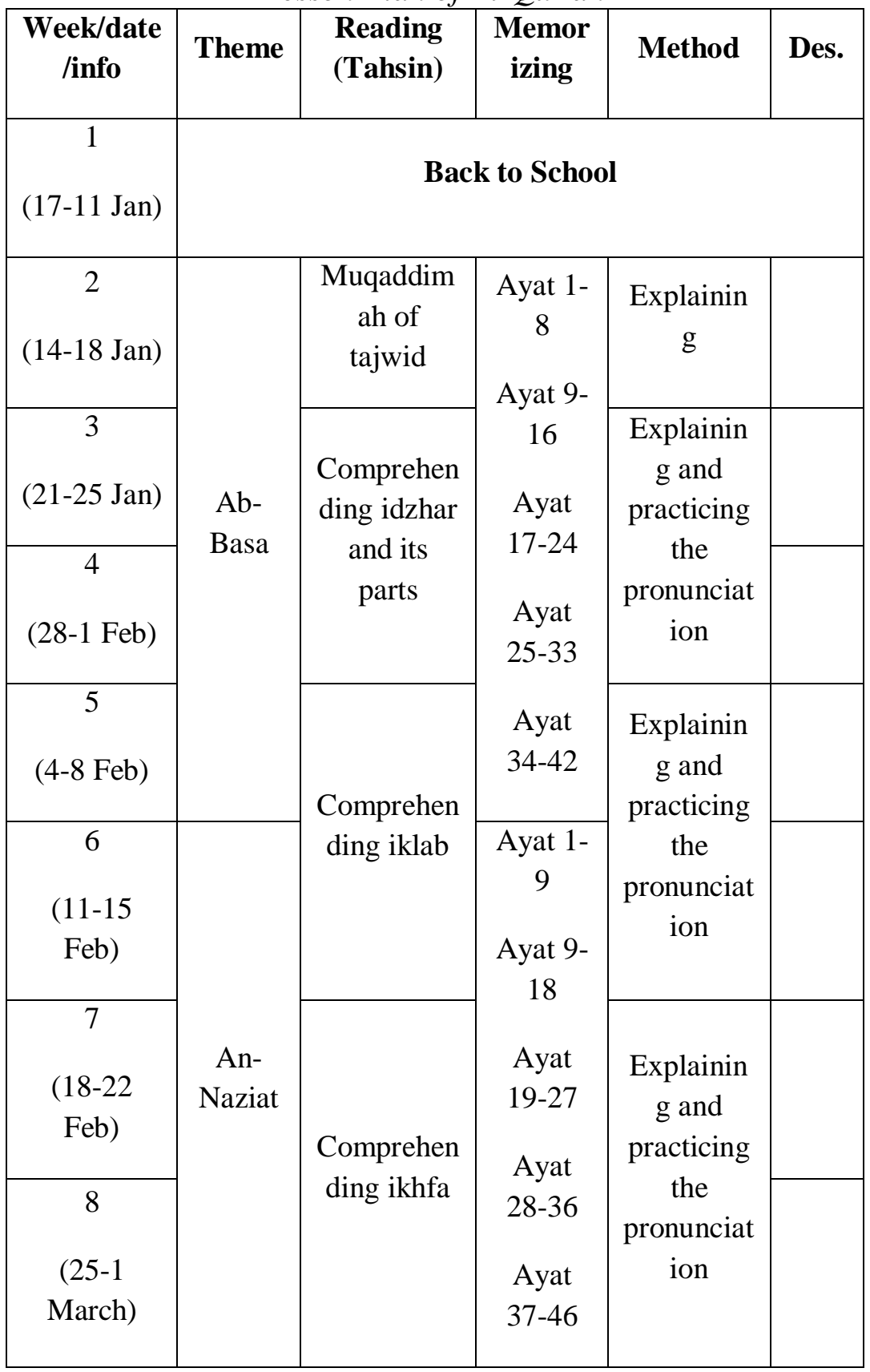




\begin{tabular}{|c|c|c|c|c|}
\hline $\begin{array}{c}9 \\
(4-8 \\
\text { March) }\end{array}$ & \multirow{3}{*}{$\begin{array}{c}\text { An- } \\
\text { Naba }\end{array}$} & & $\begin{array}{l}\text { Ayat 1- } \\
8 \\
\text { Ayat 9- }\end{array}$ & \\
\hline $\begin{array}{c}10 \\
(11-15 \\
\text { March) }\end{array}$ & & \multirow{2}{*}{$\begin{array}{c}\text { Comprehen } \\
\text { ding iklab }\end{array}$} & $\begin{array}{c}\text { Ayat } \\
17-24\end{array}$ & $\begin{array}{l}\text { Explainin } \\
\mathrm{g} \text { and } \\
\text { practicing }\end{array}$ \\
\hline $\begin{array}{c}11 \\
(18-22 \\
\text { March) }\end{array}$ & & & $\begin{array}{c}\text { 25-32 } \\
\text { Ayat } \\
33-40\end{array}$ & $\begin{array}{l}\text { the } \\
\text { pronunciat } \\
\text { ion }\end{array}$ \\
\hline $\begin{array}{c}12 \\
(25-29 \\
\text { March) }\end{array}$ & \multicolumn{4}{|c|}{ Market Day } \\
\hline $\begin{array}{c}13 \\
\text { (1-5 April) }\end{array}$ & & \multirow{3}{*}{$\begin{array}{c}\text { Comprehen } \\
\text { ding } \\
\text { idghom } \\
\text { bighunnah } \\
\text { and } \\
\text { bilaghunna } \\
\text { h }\end{array}$} & & $\begin{array}{l}\text { Explainin } \\
\mathrm{g} \text { and } \\
\text { practicing } \\
\text { the } \\
\text { pronunciat } \\
\text { ion }\end{array}$ \\
\hline $\begin{array}{c}14 \\
(8-12 \\
\text { April) }\end{array}$ & $\begin{array}{c}\text { Al- } \\
\text { Muthof }\end{array}$ & & \multirow{2}{*}{$\begin{array}{c}\text { Ayat } 1- \\
36\end{array}$} & \\
\hline $\begin{array}{c}15 \\
(15-19 \\
\text { April) }\end{array}$ & fifin & & & \\
\hline $\begin{array}{c}16 \\
(22-2\end{array}$ & $\begin{array}{c}\text { Al- } \\
\text { Infitho }\end{array}$ & $\begin{array}{c}\text { Comprehen } \\
\text { ding mad }\end{array}$ & & $\begin{array}{l}\text { Explainin } \\
\mathrm{g} \text { and } \\
\text { practicing }\end{array}$ \\
\hline
\end{tabular}




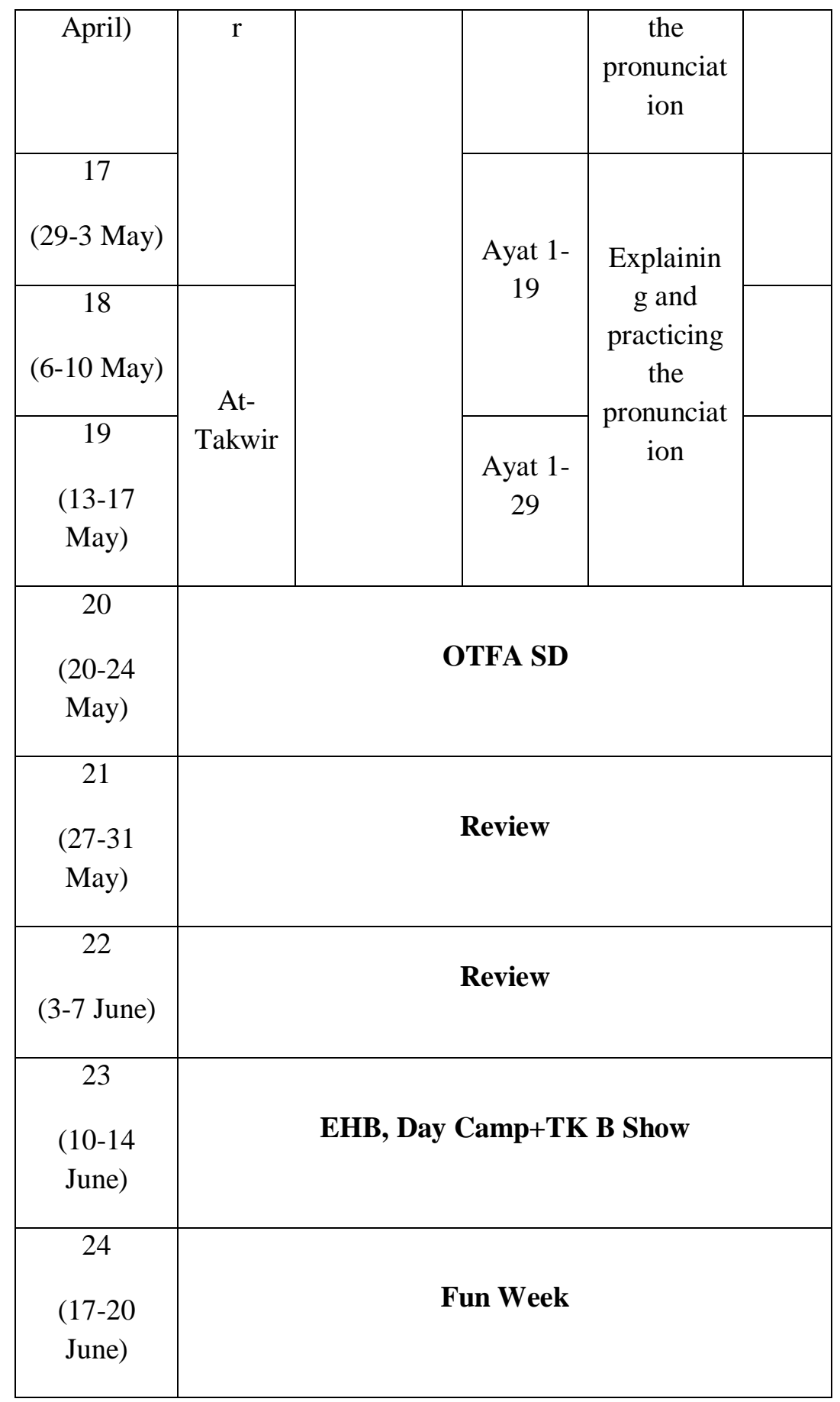

TA'DIB, 20 (1), 2015, 35-56 
\begin{tabular}{|c|c|}
\hline 25 & Giving the Report \\
(22 June) & \\
\hline
\end{tabular}

Broadly, the Sekolah Alam Indonesia has a purpose to: (1) develop the good character, (2) foster the spirit of leadership, (3) sharpen the logical thinking, build a tradition of scientific thinking. While, the vision of the Sekolah Alam Indonesia is, "realizing the international standard education institutions which could produce the leader generations who have good character and sharpness of scientific logic, which enabled them to make changes and bring benefit to the citizen of Indonesia in particular, and humanity in general.

Learning material planning at Sekolah Alam Indonesia is jointly conducted by the school principal and teachers. Learning material in this school is in the form of themes, each theme should be completed over two, four, or five weeks in accordance with the theme that must be implemented. These themes are changed every year, so it is not monotonous. For a clearer description of learning material planning, it can be seen from the Lesson Plans used.

\section{Tabel 4}

Lesson Plan of Sekolah Alam Indonesia

\section{UP 1 (19-23 Agustus): QS. Al-Lail}

Class : UP Elementary School 2-6 Group 2

Objectives

Cognitive : Students may know, mention and write letters hijaiyah, memorize surah al - Lail.

Affective : Students can listen to the teacher well.

Psychometrics : Students can adhere to good teacher instruction. 
Devices and Materials (Speaker, Murotal, Hijaiyah card)

Time allocation ( 1 x 30 minutes $)$

U 1.1 Opening (10 minutes)

\begin{tabular}{|l|l|l|}
\hline Subject & Activities & Expression \\
\hline Teacher & Greeting & Assalamualaikum \\
\hline Teacher & Delivering lesson & We will review surah..... \\
\hline Teacher & Giving instruction & $\begin{array}{l}\text { Listen and keep } \\
\text { attention }\end{array}$ \\
\hline Teacher & Motivating the students & Try to learn \\
\hline Teacher & Giving instruction & Be quiet when studying \\
\hline
\end{tabular}

U 2. Core Explanation (20 Minutes)

Background

In order to memorize Qur'an well, then the students have to repeat what has been memorized until all memorization is correct. And in order not to forget the previous memorization because of the new one, the students should repeat it every day.

Like the teachers says: let's repeat the last memorization, then we memorize surah / next ayat ...!

To keep the students do not make mistake in reading, the teacher always exemplifies the correct reading beforehand by mentalaqi directly to each student in turn.

Like the teachers says: listen and follow what the teacher reads!

The students can comprehend the instruction well and can practice it.

TA'DIB, 20 (1), 2015, 35-56 
Like the teacher says: please keep attention and be quiet!

The first meeting

\begin{tabular}{|l|l|l|}
\hline Student & Tahsin & Tahfidz \\
\hline All students & Al Barqi page 13 & Al-Lail ayat 1-2 \\
\hline
\end{tabular}

The second meeting

\begin{tabular}{|l|l|l|}
\hline Student & Tahsin & Tahfidz \\
\hline All student & Al Barqi page 13-14 & Al Lail ayat 3 \\
\hline
\end{tabular}

The third meeting

\begin{tabular}{|l|l|l|}
\hline Student & Tahsin & Tahfidz \\
\hline All students & Al Barqi page 14 & Al Lail ayat 4 \\
\hline
\end{tabular}

The forth meeting

\begin{tabular}{|l|l|l|}
\hline Student & Tahsin & Tahfidz \\
\hline All students & Al Barqi page 14-15 & Al Lail ayat 5 \\
\hline
\end{tabular}

\section{U3. COVER}

Discussing students' activities

1. The teacher asks the students about what they have memorized.

2. The students repet the ayat they have memorized together.

3. The teacher remember the students to be discipline and focus on the learning.

4. Closing 
2. The Implementation of Islamic Education Learning at Sekolah Alam Indonesia Palembang

After the lesson plans have been completed, the next teacher's task is implementing what has been planned in the teaching and learning activities in their classroom. Based on the observations has been done, the learning activities begins at 7:15 with the theory of Islamic Education delivered by each classroom teachers. The material is in the form of the daily worship practice. Every day before starting the study, students are asked to report the results of their juz'amma memorization which is targeted to be finished when they are in the $5^{\text {th }}$ grade and comprehend juz 30. Then, the core activities, this stage is the core stage of learning activities series done by teachers and students in achieving a goal that is contained in the daily activities unit, in the implementation of learning, the teachers use direct practice method.

For a schedule of daily activities of Sekolah Alam Indonesia students is as follows:

\section{Table 5}

Learning Activities of Islamic Education lesson

\begin{tabular}{|c|l|c|}
\hline Grade & \multicolumn{1}{|c|}{ Types of Activity } & Time \\
\hline \multirow{4}{*}{ I } & $\begin{array}{l}\text { Delivering Islamic Education materials } \\
\text { and Practicing daily worship such as } \\
\text { ablution and praying }\end{array}$ & $07.15-07.30$ \\
\cline { 2 - 3 } & Reporting juz'amma memorization & $07.30-08.30$ \\
\cline { 2 - 3 } & Teaching and learning activity & $08.30-09.30$ \\
\cline { 2 - 3 } & Tahsin & $09.30-10.30$ \\
\cline { 2 - 3 } & Taking a rest & $10.30-11.00$ \\
\cline { 2 - 3 } & Learning activity & $11.00-12.15$ \\
\cline { 2 - 3 } & Saying Dzuhur prayer together & $12.15-12.45$ \\
\hline
\end{tabular}

TA'DIB, 20 (1), 2015, 35-56 


\begin{tabular}{|c|c|c|}
\hline & Evaluating learning activity & $12.45-13.00$ \\
\hline \multirow{9}{*}{ II } & $\begin{array}{l}\text { Delivering Islamic Education materials } \\
\text { and Practicing daily worship such as } \\
\text { ablution and praying }\end{array}$ & $07.15-07.30$ \\
\hline & Reporting juz'amma memorization & $07.30-08.30$ \\
\hline & Teaching and learning activity & $08.30-09.30$ \\
\hline & Tahsin & $09.30-10.30$ \\
\hline & Taking a rest & $10.30-11.00$ \\
\hline & Learning activity & $11.00-12.15$ \\
\hline & Saying Dzuhur prayer together & $12.15-12.45$ \\
\hline & Studying & $12.45-14.00$ \\
\hline & Evaluating learning activity & $14.00-14.30$ \\
\hline \multirow{9}{*}{ III-VI } & $\begin{array}{l}\text { Delivering Islamic Education materials } \\
\text { and reading short (surah an-naas and } \\
\text { soon) }\end{array}$ & $07.15-07.30$ \\
\hline & Reporting juz'amma memorization & $07.30-08.30$ \\
\hline & Teaching and learning activity & $08.30-09.30$ \\
\hline & Tahsin & $09.30-10.30$ \\
\hline & Taking a rest & $10.30-11.00$ \\
\hline & Teaching and learning activity & $11.00-12.15$ \\
\hline & Saying Dzuhur prayer together & $12.15-12.45$ \\
\hline & Taking a rest and having lunch & $12.45-13.30$ \\
\hline & Learning and guiding activities & $13.30-15.00$ \\
\hline
\end{tabular}




\begin{tabular}{|l|l|l|}
\hline & Evaluating learning activity & $15.00-15-30$ \\
\hline
\end{tabular}

The table above is a daily activity of Sekolah Alam Indonesia students, starting from delivering Islamic education materials from each classroom teachers. The materials contain short and simple explanations about Islamic education, such as daily prayers and reading short surah. Teaching and learning activities in Sekolah Alam are different in each classroom. For grade I, it starts at 07:15 a.m to 1 p.m, grade II at 07:15 a.m to 2:30 p.m. , and grade II-VI the study time is at 7 a.m. to 15:30. Before starting regular learning activities, the students report their memorization with the guidance from their classroom teachers. The next activity is tahsin. The one which is used in Sekolah Alam Indonesia is Tahsin Utsmani. Followed by regular learning. Regular study schedule adjusted to the existing schedule, then the free play (rest), followed by regular material II which is appropriate to the schedule. The next activity is taking ablution and saying prayer, the way to take ablution is children are taught to pray before and after taking ablution guided by the teacher. One of the boys will be appointed to the priesthood and guided by the teacher. The next activity is having nutritious lunch (rice, side dishes and vegetables). In this lunch time, the students are encouraged to bring their own food from home. The last activity is the preparation of going home, in this activity, the teacher evaluates all activities from the beginning to the ending.

\section{The Evaluation of Islamic Education Learning at Sekolah Alam Indonesia Palembang}

Evaluation is the last stage of all learning activities. At Sekolah Alam Indonesia, the evaluation of teaching and learning activities is carried out every day, by observing the students' behavior in everyday life continuously which aims to determine their development and behavior. The teachers in Sekolah Alam Indonesia also evaluate in the closing stages.

TA'DIB, 20 (1), 2015, 35-56 
In addition, the evaluation is also conducted in the form of test. The test used in Sekolah Alam Indonesia is an oral and written test. This oral test is conducted every semester. The oral test is in the form of the practice exams, in which the students practice what they have learned in school Alam Indonesia. While for written test, is conducted each semester as the tests in general.

Table 6

Weekly Report Sheet

\begin{tabular}{|c|c|c|}
\hline $\begin{array}{l}\text { Subject } \\
\text { Class }\end{array}$ & \multirow{2}{*}{\multicolumn{2}{|c|}{$\begin{array}{lll}: \text { Al-Qur'an } & \text { Semester } & : 1 \\
: \text { SD 2-6 }(\text { Group 1) } & \text { Year } & : \text { 2013/2014 } \\
: \text { 16 (18-22 Nov 2013) Teacher } & : \text { Azizul Gopur }\end{array}$}} \\
\hline Week & & \\
\hline Day/Date & Theme & Evaluasi \\
\hline $\begin{array}{l}\text { Monday, } \\
\text { Nov } 18^{\text {th }}, \\
2013\end{array}$ & Al Humazah & $\begin{array}{l}\text { Pandi disturbs his sisters and brothers, } \\
\text { and likes to joke, even to the teacher. } \\
\text { Maryam is selfish to her friend. Hisyam } \\
\text { ikes doing both mistakes }\end{array}$ \\
\hline $\begin{array}{l}\text { Wednesday, } \\
\text { Nov } 20^{\text {th }} \\
2013\end{array}$ & Al Humazah & $\begin{array}{l}\text { The classroom condition today is more } \\
\text { controlled. Fandi still likes playing } \\
\text { while studying. For the others, there is } \\
\text { to problem. }\end{array}$ \\
\hline $\begin{array}{l}\text { Thursday, } \\
\text { Nov } 21^{\text {st }} \text {, } \\
2013\end{array}$ & Al Humazah & $\begin{array}{l}\text { Fandi still likes joking when reporting } \\
\text { memorization. The others are more } \\
\text { bbedient. }\end{array}$ \\
\hline $\begin{array}{l}\text { Friday, } \\
\text { Nov } 22^{\text {nd }}, \\
2013\end{array}$ & Al Humazah & $\begin{array}{l}\text { Hisyam should be given the } \\
\text { consequence if he does not focus on the } \\
\text { esson. For the pronunciation, Fandi, } \\
\text { Willy, and Ryu should be guided more. }\end{array}$ \\
\hline Weekend & Akhlak & Not mocking at friends' weaknesses \\
\hline
\end{tabular}




\begin{tabular}{|l|l|l|}
\hline evaluation & Leader Ship & Focus on the lesson \\
\cline { 2 - 3 } & Kognitif & $\begin{array}{l}\text { Memorizing surat al Adiyat and al } \\
\text { Bayyinah }\end{array}$ \\
\hline
\end{tabular}

The table above is a table of Islamic education subject evaluation that explains the repeated memorization every week.

Reports of student learning will be delivered in book report. To assess student learning outcomes, Alam Indonesia issued two school report books, achievements and portfolio report books. Achievement report book is used to provide an assessment of student learning outcomes that is measured in terms of value or numbers. While, the portfolio or moral report book, is the one that contains the statements of students' good character and behavior. Morality report book serves as the connecting book.

\section{E. Conclusion}

The conclusion of this study is the learning process in Sekola Alam Indonesia is appropriate to the study of the planning, implementation, and evaluation theories. Planning instruction consists of the planning of annual program, semester program, weekly activity unit, and daily activities unit. In the implementation, the learning process in Sekolah Alam Indonesia is appropriate to the planning that has been made. While, for evaluating the learning process, the test is conducted in the form of oral and written test. 


\section{References}

al-Qattan, Manna Khlail. Studi Ilmu-ilmu Al-Qur'an, Terj. Mudzakir As. Bogor: Pustaka Litera Antar Nusa.

Alston, Margaret and Wendy Bowles. (1998). Research For Social Worker: An Introduction to Methods. Australia: Allen ang Unwin.

Arikunto, Suharsimi. (2006). Prosedur Penelitian. Jakarta: PT. Rineka Cipta.

Daradjat, Zakiyah. (1996). Ilmu Pendidikan Islam. Jakarta: Bumi Aksara

Hamalik, Oemar. (1994). Media Pendidikan. Bandung: Citra Aditya Bakti

Marimba, Ahmad D. Pengantar Filsafat Pendidikan Islam. Bandung: Al-Maarif

Soehartono, Irawan. (1995). Metode Penelitian Sosial. Bandung : PT. Remaja Rosdakarya

Susanto, Ahmad. (2013). Teori Belajar dan pembelajaran di Sekolah Dasar. Jakarta: Kencana Prenada Media Group

Syarifuddin, Amir. Ushul Fiqih Jilid 2. Jakarta: Logos Wacana Ilmu

UUD 1945. (2004). UU Republik Indonesia dan Perubahannya. Jakarta: Penabur Ilmu

Zuhairini, dan Abdul Ghafir. (2004). Metodologi Pembelajaran Agama Islam. Malang: Universitas Malang 